\title{
Capping the tenure of CEOs as a Good Corporate Governance Strategy: Prospects and Challenges
}

\author{
Paradzai Munyede ${ }^{1 *}$ \\ ${ }^{1}$ Institute of Peace, Leadership and Governance, College of Business, Peace, Leadership and \\ Governance, Africa University, Mutare, 1320, Zimbabwe.
}

Received: 2020-10-27; Accepted: 2021-04-13; Published: 2021-04-30

\begin{abstract}
The concept of good corporate governance has gaining traction over the last three decades in the private and public sectors as a response to serious financial scandals and maladministration practices in organisations around the globe. Antidotes provided in previous studies on these corporate failures attributed this to poor board compositions and inadequate separation of power. Whilst this was part of the problem, little effort was put to understand how Chief Executive Officers (CEOs) term limits could also contribute to good governance practice which would make organisations avoid scandals. Therefore, the purpose of this paper is to explore how capping CEOs tenure could enhance good corporate governance in the public and private sectors. This paper is based on a qualitative approach and used content analysis to review data from published records like journal articles. This article posited that capped term limit in both the public and private sectors is ideal as it enhances good corporate governance practice which in turn will make institutions effective and responsive to changes in their operating environment.
\end{abstract}

Keywords: Good Corporate Governance; CEOs Tenure; Corporate Governance Instruments; Chief Executive Officer

How to Cite: Munyede, P. (2021). Capping the tenure of CEOs as a Good Corporate Governance Strategy: Prospects and Challenges. Journal of Contemporary Governance and Public Policy, 2(1), 67-78. https://doi.org/10.46507/jcgpp.v2i1.29.

Permalink/DOI: https://doi.org/10.46507/jcgpp.v2i1.29 


\section{Introduction}

The issue of capping Chief Executive Officers (CEOs) tenure as a good corporate governance practice has eluded most of the academic debates. Most debates have focused on board composition and the relationship between board and management. Literature by scholars like (Coyle, 2015) have concentrated on good corporate governance and compensation for executives. In terms of trying to understand how capping of CEOs tenure could add to the promotion of good corporate governance practice, (Whitehead, 2011) stated that there is paucity of literature covering this area. Therefore, this paper argues that the issue of capping of term limits is of great importance in upholding good corporate governance practices both in the private and public sectors. To butress, this (Okeahalam \& Akinboade, 2003) argues that good corporate governance practices are a prerequisite for organisational performance and economic growth when they stated that,

Corporate governance has implications for economic development especially in helping to increase the flow of financial capital to firms in developing countries. This is quite important for policymakers in Africa who are concerned with attaining high long-term growth rates of about 7 percent per annum within the framework of the New Partnership for Africa's Development (NEPAD). Without efficient companies or business enterprises, a country will not create wealth or employment. Without investment, companies will stagnate and collapse. If business enterprises do not prosper, there will be no economic growth; no employment, no taxes paid and invariably the country will not develop. Developing countries, in particular, need wellgoverned and managed business enterprises that can attract investments, create jobs and wealth and remain viable, sustainable, and competitive in the global market place. Good corporate governance, therefore, becomes a prerequisite for national economic development.

This was also collaborated by (World Bank, 2014) which maintains that good corporate governance practices are one of the elements which are beneficial to both private and public sector organisations as it improves access to financial markets, reduces risks of scandals, improves strategic decision-making processes, reduces corruption whilst improving transparency and accountability.

\section{Background to Corporate Failures and the role of CEOs}

From the 1980s repeated serious frauds, financial abuses, boardroom tussles, and corporate collapses both in developing and developed countries have brought to the fore the need to relook at how corporate governance practices are being followed in both public and private sector organisation, (Mandala, Kaijage, Aduda, \& Iraya, 2017). This was also reinforced by Benz \& Frey, (2007) when they stated that over the last three decades, the corporate world was rocked by huge scandals which caused share prices to plummet due to excessive managerial compensation and manipulation of accounting records. Some of the scandles in the private sector are Enron in 2001, HIH Insurance Ltd of 
Australia, World Com, East African Portland, and National Bank of Kenya, (Edwards et al., 2012; Mandala et al., 2017). The scourge of scandals also affected the public sector with notable cases being the 15 members of the European Union who resigned in 2002, a member of the Metropolitan police in England who stole over 5 million pounds in 1995 (Matei \& Drumasu, 2015). In the Zimbabwean context (Ncube \& Maunganidze, 2014) highlighted the following cases with notable transgressions against good corporate governance practices, mega remunerations at Zimbabwe Broadcasting Corporation, Public Service Medical Aid Society and Harare City Council to name a few. Whilst recommendations and corrective measures were made to address these corporate failures, these antidotes did not look if Ceo's tenure could also be a contributing variable in causing the scandals.

Whilst there is extensive literature covering board composition, company performance and top management compensation, there is thin academic research in understanding if capping Chief Executive Officers (CEOs) could be used to enhance corporate governance. The few studies done to date by scholars like (Whitehead, 2011) focused on the private sector only. In terms of research relating to term limits in the public sector, it's even thinner, therefore this paper intends to analyse the extent to which capping of CEOs tenure in the public and private sector could contribute to the observance of good governance practices by organisations.

\section{Research Methods}

This study is anchored on qualitative research design with content analysis being adopted in interpreting data inorder to gain more clarity . According to (Leavy, 2014), content analysis is an approach that allows interpretation of meaning from documentation and texts which includes newspapers, books, web pages as well as articles. In other words, it is a method that makes a valid inference from texts. Due to limitations imposed by the novel coronavirus (COVID-19), this method became compatible with this study as it allows meaningful analysis of available records inorder to provide a meaningful conclusion. Therefore this study utilised data collected from published journals, reports, web pages, and legal documents.

\section{Results and Discussion}

\section{International, Regional and National Instruments on Corporate Governance}

In response to various corporate scandals, governments and competent bodies responded by toughening corporate governance laws as well as imposing sanctions to corporates which did not implement ethical and transparency practices (Matei \& Drumasu, 2015). In terms of corporate governance instruments (Coyle, 2003) pointed out that the government of the United States of America is the only country which enacted legislation to regulate the activities of companies. The legislation became known as the Sarbanes-Oxley act of 2002 which among other things introduced a raft of measures including the following provisions, punishing audit firms which certify false information, the establishment of independent audit committee which included independent members, independence and integrity of external auditors. In terms of CEOs, the act states that the individuals must not have been an employee of the companies audit company and that he/she must sign 
annually and certify that the financial statement represents the true state of affairs.

Though the Sarbanes-Oxley Act of 2002 is held as a millstone in improving corporate good governance, its main weakness is that, firstly, it did not address the issue of CEO's tenure which is a significant area of interest in the promotion of good corporate governance practice. Secondly, the act is directed more to the private sector than the public sector as it places more emphasis on regulating trading of securities of listed companies on the New York Stock Exchange. However, the act provides a strong basis to examine how a CEO's tenure could be looked at in terms of how it can enhance good corporate governance practices.

In the United Kingdom, the country followed a different approach as they adopted a voluntary instrument known as the Combined Code of 1998. The Combined Code is a culmination and consolidation of prior works namely, Cadbury, Greenbury, Hampel, Turnbull, Smith, and Higgs reports. According to (Coyle, 2003) the code covered a lot of areas that promote good corporate governance. The areas include the separation of the roles and functions of Chairman and CEO to ensure that the board is not dominated by a few individuals. Further, the code stipulates that the CEO's remuneration must be disclosed in the annual financial statements by category showing share options, bonuses, and any performancerelated incentives. The major weakness of this code is similar to that of the Sarbanes-Oxley Act as discussed above.

The South African corporate governance instrument known as the King's report was greatly influenced by the Combined Code of the United
Kingdom as its compilation has input from Sir Adrian Cadbury. This code is also a voluntary code meaning its application depends on the willingness of organisations. According to the (Institute of Directors of Southern Africa (IODSA) (2016), the Kings report complements other international instruments by promoting sound corporate governance through adding issues that apply to the South African context. However, the report introduces the African philosophy of "Ubuntu" as the point of reference in governance because it is anchored on principles of integrity, communalism, mutual respect, human dignity, sharing, and accountability. This philosophy emphasizes the necessity for organisations to understand the reciprocal relationship which they enjoy with communities because this cordial relationship leads to sustainable development which will be beneficial to both parties.

Another important feature of the King's report is its emphasis on leadership and ethics as it posits that the success of organisations is dependent on the ethical behaviors of the leaders who include CEOs. In a major departure from other codes, the report explicitly covers the private and public sector and it uses the following nomenclature organisations, this encompasses both private sector governing institutions. The Kings Report explicitly covers in detail the following, Local governments, State-Owned Entities, Non-Profit Organisations, Retirement Funds as well as Small and Medium Enterprises. Despite making good coverage of important governance matters, the capturing of Ceo's tenure as a key element in good corporate governance remains elusive, as it is not covered.

The National Code on Corporate Governance Zimbabwe 
(2014) also referred to as the National Code and the Public Entities Corporate Governance Act, Chapter (10:31) are the instruments guiding corporate governance in Zimbabwe. The National Code covers other contentious issues in corporate governance like, board composition, the establishment of the audit committee, size of boards and remuneration of management but its silent on the issue of CEOs tenure which this study argues that its a critical component in enhancing good corporate governance practice by both public and private organisations. The Public Entities Corporate Governance Act, Chapter (10:31) under section 17 provides that Ceo's tenure must be limited to two five year terms. However, the major challenge with this provision is that it is in variance with what happens in practice as CEOs in most public organisations do not leave office after the end of their tenure as they are always reassigned or rotated to other ministries or sister organisations.

\section{The Purpose of CEOs in Promoting Good Corporate Governance}

World Bank (2009) posits that good corporate governance practices ensure stability and viability of organisations whilst its weaknesses will lead to reduced investor confidence failing to attract new capital which will lead to the collapse of an entity. Closely related to this is the role played by leadership and culture in shaping the foundation and direction of the organisation. Schein (2004) postulates that CEOs as leaders are a critical cog in shaping the values and beliefs of group members to focus on a common objective. In this regard, a CEO who sets a culture based on such values as ubuntu, accountability, transparency, responsibility, fairness, and integrity, will be fulfilling key tenents of corporate governance (Matei \& Drumasu, 2015). In policy or decision-making process, the CEO has to ensure that the whole process is not opaque but it is transparent and can be verified by all those who will be affected by it. To this end (Edwards, Halligan, Horrigan, \& Nicoll, 2012b) agree that strong leadership by CEOs based on good ethics is ideal for success for organisations. For example, if CEOs remuneration is set within agreed limits, this same shared meaning will cascade to all levels of the organisation, if he or she does the opposite, then most workers will agitate for salaries which do not relate to their positions.

The Ceo is also responsible for establishing comprehensive risk management, compliance, and assurance system. He/She is also tasked in ensuring that good corporate governance practices are upheld by setting a clear accountability mechanism that protects organisational assets from pilferage and abuse (Edwards et al., 2012a). Matei and Drumasu (2015) reiterated that upholding of good corporate governance practices by CEOs contributes to efficient utilization of financial resources, decreases budget deficits, elimination of corruption which in turn will result in improved performance by the entity in the provision of goods and services.

According to the (Institute of Directors of Southern Africa, 2016), the CEO is also responsible for providing ethical leadership which is evidenced by his/her competence, integrity, and fairness in handling affairs of the organisation. Internally, the CEO has the responsibility to ensure that decision making meetings are held regularly as these help in shaping the policy and direction of the organisation. He or She must 
ensure that appropriate spaces of engagement with stakeholders are available and meetings are held accordingly and correct information is disseminated to all intended recipients. The integrity of CEOs is also tested during a process like procurement as this activity constitute a large proportion of most organisations expenditure lines, (Munyede \& Mapuva, 2019). Therefore, if the procurement process is done above board it translates to better services to clients which will create a good relationship whilst procurement mirred in corruption deprives citizens of quality goods and services.

Further, it is the responsibility of the CEO to ensure compliance with laws and regulations to safeguard the interest of the organisation. Failure to comply with laws like paying taxes timeously exposes the organisation to penalties or even closure by the government. Through the CEO organisations gains, credibility through publishing audited Financial accounts which act as evidence of good stewardship on behalf of stakeholders. According to (Coyle, 2015) audited financial statements act as a barometer to which an organisations performance is measured. Since audited financial statements disclose itemised top executive's remuneration, this provides a transparent measure of knowing emoluments of top managers thereby ensuring that agreed levels are maintained.

The CEO is also the sounding board for the Board of Directors as he provides advice on company performance, the status of assets, human capital requirements, and dissemination of accurate information within and outside the organisation. Organisation for Economic Co-operation and Development (OECD), (2011) points out that the CEO is also responsible for communicating policy issues relating to the performance of the organisation and corporate social responsibilities. Communicating an organisations policies and operational standards helps recipients to understand and measure how such entity will be following good governance practices.

\section{CEOs as a Corporate Construct}

In most countries, the term CEO is ascribed to a position occupied by a top executive in the private sector. It embodies the head of a corporation which might be a listed company or a small family-owned business. The CEO is viewed as the figurehead who is a link between the board of directors and staff members. In the Public Sector, the term CEO is also known by different titles such as Permanent Secretary, Executive Secretary, Town Clerk, ViceChancellor, or Commissioner-General. Despite the various titles, they all have a common title that is Accounting Officer which equates them to CEOs in the private sector.

The CEOs in the public and private sectors are shaped by the environment under which they operate. Though both are affected by social, technological, legal, economic, and political environments the degree of influence differs greatly. In terms of political, social, and legal environment public sector managers are greatly affected because public organisations which they preside over, are responsible for provision of public goods and services. These goods and services attract politicians who exert pressure on the CEO so that these goods benefit certain priority areas mainly their electrolate. In terms of legal provisions, CEOs in the public sector lacks flexibility as they operate around a framework regulated by a 
plethora of laws, regulations, circulars, and codes of conduct. For example, most constitutions assign the responsibility of Human Rights to public institutions, so the CEOs as heads become the duty bearers whose mandate will be to ensure their fulfillment for the benefit of rights holders. The failure to comply with fulfilling the human rights provisions will result in CEOs and their institutions being arraigned before the courts for failing to follow constitutional provisions. This has the effect of shaping CEOs to be bureaucratic and less creative as they would want to avoid being punished if they transgress beyond the various legal instruments.

The CEOs in the private sector are insulated from compliance to a lot of these regulations, but they are shaped greatly by the dynamic changes which occur in the competitive business environment of the private sector. They are also greatly affected by the technological changes which dictate how products are processed, therefore to remain viable the CEO will always be racing to identify new technologies that will give them an edge over competitors.

\section{Generic Working Conditions of CEOs}

In the private sector, the remuneration committee has the mandate of setting the working conditions for CEOs, (Institute of Directors of Southern Africa, 2016). To safeguard from personal interests, the membership of this committee is composed of independent members. The mechanism in the private sector gives the CEO a platform to negotiate his or her conditions of service with the committee. However, (Coyle, 2015) noted that there are challenges encountered in setting up conditions of service for CEO's especially in trying to balance between an attractive package and the ability to retain the right skilled staff. He further pointed that another challenge encountered in setting conditions of service is when an organisation operates a unitary board whereby the Chairman will also be the CEO because such individuals will be wielding significant influence over other board members. This situation is exacerbated if the Chairman would have been the CEO long time and this gives them the ability to erode the power of the remunerations committee. Whilst a CEO with a short tenure lacks the influence to negotiate a higher package as he/she will be trying to establish himself which he/she will try to do by achieving agreed targets thereby improving organisational performance. However, due to higher compensation and packages most private organisation always offer capped CEO tenure linked to performance usually two five year terms.

In the public sector, most CEOs do not have the flexibility of negotiating conditions of service as these are predetermined by an organ or institution which has mandate such as the Public/Civil Service Commission. In most cases, working conditions for CEOs in State-Owned Enterprises and local governments are agreed at institutional level but are subject to review by line ministry. This was collaborated by (Janke, Propper and Sadun, 2019) when they posited that the appointment of CEOs in the public sector is not entirely to the board of directors of the StateOwned Enterprise or local government but it is reviewed by line Ministries which has the ultimate power to determine the appointment of candidates as well as their conditions of service. Some of the appointments are also recommended by the Cabinet or Commissions for approval by parliament or the 
President of that country. In can be seen that working conditions in the public sector is not a straight forward affair, but it follows a series of multilayered levels of bureaucracy.

In terms of compensation, (Hickman \& Lee, 2001) states that in the public sector, it is linked to functions and position, not to profitability. They further highlighted that compensation is not entirely linked to meritocracy and performance but the length of service. To understand the different conditions of service for CEOs in the public and private sectors, the following comparative table gives such analysis.

Table 1: Comparative benefits between CEO in private and public sector

\begin{tabular}{|c|c|c|}
\hline ITEM & CEO & \\
\hline & Private Sector & Public Sector \\
\hline Salary-Fixed & yes & yes \\
\hline -Performance-based & yes & - \\
\hline Housing & Yes & yes \\
\hline Share Options/Equity & yes & - \\
\hline Board meeting allowance & yes & - \\
\hline Motor vehicle and fuel & yes & yes \\
\hline Severance allowance & Yes & yes \\
\hline Security Guard & Yes & - \\
\hline House Maid & yes & - \\
\hline Telephone Allowance & yes & yes \\
\hline Medical aid cover & yes & yes \\
\hline Funeral cover & yes & yes \\
\hline Pension Scheme & yes & yes \\
\hline Education allowance & yes & yes \\
\hline Vacation Leave days & yes & Yes \\
\hline Annual Bonus & Performance-based & yes \\
\hline Subscriptions to professional boards & yes & - \\
\hline Holiday Allowance & yes & - \\
\hline Working Hours & Flexible & Fixed \\
\hline
\end{tabular}

Source: Processed by the author (2021)

It can be noted that working conditions for CEOs in the private sector are better as compared to the private sector. 


\section{Uncapped CEOS Term Limits: Debates}

As the chorus to uphold good corporate governance practices grows, two distinct competing debates have emerged. The first school of thought argues that tenure of CEOs in public and private organisations must be capped in line with presidential term limits found in most democratic constitutions as they argue that a President is the CEO of the country. This school of thought argues that, since most Presidents have a constitutional two five-year term limit, this must then be cascaded to all public and private sector organisation. Proponents for this school of thought like (Benz \& Frey, 2007) argue that for example in the United States of America there are two four year term limits applicable to the president and this can also being applied to CEOs in the corporate world. Choruma (2019) reaffirms this line of thought when he stated that the Constitution of Zimbabwe Amendment No (20) of 2013, section 95 give two five year terms to the Head of State and Government, therefore the same must be extended to leaders in the public and private sectors. This was also supported by (Mohd-Saleh, MohdSanusi, Abd-Rahman, \& Bukit, 2012) who argue that short-tenured CEOs uphold good corporate governance practices as their disclosure of information to the board of directors and shareholders is more transparent because they would be trying to prove their integrity and reputation.

However, the major drawback of this argument, is that in countries with weak democratic institutions, constitutions are amended to allow incumbent (Presidents) to extend their hold to power for perpetuity. Because of such blatant constitutional transgressions, it also becomes impossible to then put term limits to
CEOs especially in the public sector. This argument is also silent on one major contentious issue of compensation. Ideally, a higher package is more appropriate for short tenure as the CEO would be able to be cushioned once he leaves employment. In most developing countries employment opportunities are limited such that if a person leaves employment he/she might find it difficult to get another position despite that he/she might be highly skilled and qualified, therefore capping the term limit does not address this issue holistically.

The second school of thought as advanced by Whitehead (2011) argues that CEOs with uncapped term limits are necessary for organisations as they have proven leadership based on years of practical experience gained mainly inside the organisation through promotions. He critiques that a capped tenure for a CEO will make him/her short-sighted and focus on short outcomes. It is argued further that, CEOs with long tenure are beneficiary in that they focus on pursuing long term objectives which will provide good returns to organisations. Choruma (2019) is of the view that the issue of CEOs tenure is the responsibility of the Board of directors because its an internal issue that must be governed by an organisations code. Therefore, an organisation could choose either to go in favour of uncapped or capped tenure.

Those in the public sector seem to favour the uncapping of term limits for a variety of reasons. Firstly, most CEOs rise from lower ranks to higher positions through a structured internal promotional bureaucratic process, therefore it is argued that this experience can not be discarded easily. Secondly, it is argued that CEOs in the public sector are career civil servants and the sector lacks 
adequate financial resources to offer higher compensation packages therefore long tenure accompanied by a guaranteed pension will become ideal. Thirdly, the nature of services like refuse collection, road maintenance, and public lighting offered by public organisations are difficult to measure and outcomes are difficult to attach to a single individual. It is argued that unlike a CEO in the private sector where indicators such as profitability, return on capital, earnings per share, and dividend cover are easy to measure. Given such a setting uncapping of tenure becomes necessary for CEOs in the public sector.

\section{Drawbacks of uncapped Tenure}

However, there are drawbacks associated with giving CEOs uncapped tenure which goes against good corporate governance practice. According to (Whitehead, 2011) longtenured CEOs capture the board of directors resulting in (board erosion) which will result in him overruling their decision thereby affecting the principal-agent theory. This is worse in dualistic boards where the CEO is also the Chairman of the company as he/she will be wielding more power than the board. Choruma, (2019) argues that long-serving CEOs become complacent and less valueadding to the organisation. Further, uncapped tenure makes organisations become stagnate and will not regenerate themselves thereby affecting their overall performance. In terms of disclosure of information to stakeholders, longtenured CEOs are conservative as they would be unwilling to expose themselves especially when there is an issue that will affect their job security.

\section{Alternative route to cap tenure in the public sector}

To promote good corporate governance practice, this paper argues that the capping term limit is the ideal route to take. The private sector as indicated above can pay better compensation to a CEO thereby this poses no challenges. On the contrary, the public sector has challenges since remuneration is lower, however, this paper maintains that public sector organisation can have capped tenure. To cushion the CEOs in the public sector, the following can be adopted.

- Loans at concessionary rates to purchase assets like a house, vehicle, and other basic needs have to be extended to CEOs.

- To guarantee the continued flow of income, options to invest in government and municipal bonds must be availed to these top executives.

- The practical experience of these executives needs to be tapped into institutions of higher learning by creating platforms in which they come as paid lecturers, guest speakers at symposiums, and forums.

- They can also be given the space to document their experiences into books thereby creating repositories that will promote efficiency and effectiveness of the public sector.

\section{Conclusion}

Corporate governance has evolved significantly over the last three decades and continues to do so. The demands for accountability and transparency by stakeholders are becoming a prerequisite for both public and private sector organisation. This, therefore, places the CEO as a key player who should advance good corporate governance practices which include limitations of 
their tenure. Whilst the public sector and some organisation in the private sector favors uncapped tenure, this is against good governance practices as it concentrates power in the hands of an individual.

Therefore, capping of Ceo's tenure provides realistic chances of improving organisations performance either in the public or private sector. The issue of CEOs tenure is a critical variable that has a direct impact on enhancing the viability of institutions, therefore capping is in line with good governance practice.

\section{Acknowledgments}

Author thank the Institute of Peace, Leadership and Governance, College of Business, Peace, Leadership and Governance, Africa University for their supports this work.

\section{References}

Benz, M., \& Frey, B. S. (2007). Corporate Governance: What Can We Learn From Public Governance? Academy of Management Review, 32(1), 92104.

Choruma, A. (2019). Ceo term limits: Double edged sword? Retrieved from Sunday Mail website: https://www.sundaymail.co.zw/ ceo-term-limits-double-edgedsword

Coyle, B. (2003). Corporate Governance. London: ICSA Publishing Ltd.

Coyle, B. (2015). Corporate Governance. London: ICSA Publishing Ltd.

Edwards, M., Halligan, J., Horrigan, B., \& Nicoll, G. (2012a). Dimensions of Governance for the Public Sector. Australia: ANU Press.

Edwards, M., Halligan, J., Horrigan, B., \& Nicoll, G. (2012b). Rise of Corporate and Public Governance. ANU Press.

Hickman, G. R., \& Lee, D. S. (2001).
Managing Human Resources in the Public Sector: A Shared Responsibility. San Diego: Harcourt College Publishers.

Institute of Directors of Southern Africa. (2016). King IV Report on Corporate Governance For South Africa. Johannesburg: Institute of Directors Southern Africa.

Katharina Janke, C. P. (2019). The Impact of CEOs in the Public Sector: Evidence from the English NHS. Boston: Harvard Business School.

Leavy, P. (2014). The Oxford Handbook of Qualitative Research. New York: Oxford University Press.

Mandala, N., Kaijage, E., Aduda, J., \& Iraya, C. (2017). Board Structure, CEO Tenure, Firms' Charactersitics and Performance of Financial Institutions in Kenya. European Scientific Journal, ESJ, 13(31), 39. https://doi.org/10.19044/esj.20 17.v13n31p39

Matei, A., \& Drumasu, C. (2015). Corporate Governance and public sector entities. Procedia Economics and Finance, 26, 495504.

Mohd-Saleh, N., Mohd-Sanusi, Z., AbdRahman, R., \& Bukit, R. (2012). Firm performance, CEO tenure and corporate governance reporting in Malaysia. Int. J: Management Practice.

Munyede, P., \& Mapuva, J. (2019). Exploring Public Procurement Reforms in Rural Local Authorities in Zimbabwe. Journal of Public Administration and Governance, 10(1), 1-16.

Ncube, F., \& Maunganidze, L. (2014). Corporate Governance and Executive Compensation in Zimbabwean State Owned Enterprises: A Case of Institutionalized Predation. Scientific \& Academic Publishing. 
Okeahalam, C. C., \& Akinboade, C. C. (2003). A Review of Corporate Governance in Africa: Literature, Issues and Challenges. Global Corporate Governance Forum, 15(1), 1-34.

Schein, E. H. (2004). Organizational Culture and Leadership. San Francisco: Jossey-Bass.

Whitehead, K. C. (2011). Why Not A CEO Term Limit? Boston
University Law Review, 91, 12631288.

World Bank. (2009). Report on the Observance of Standards and Codes (ROSC)., Mongolia. In Corporate Governance Country Assessment. New York.

World Bank. (2014). Corporate Governance of State-Owned Enterprises. Washington DC.

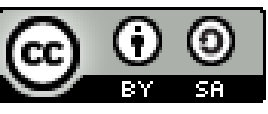

(C) 2021 by Authors. Submitted for possible open access publication under the terms and conditions of the Creative Commons Attribution (CC BY SA) license (https://creativecommons.org/licenses/by-sa/3.0/). 